\title{
How Fast is Fast Enough? Education Students' Perceptions of Email Response Time in Online Courses
}

\author{
Ching-Wen Chang \\ Missouri State University \\ Beth Hurst \\ Missouri State University \\ Annice McLean \\ Missouri State University
}

Follow this and additional works at: https://bearworks.missouristate.edu/articles-coe

\section{Recommended Citation}

Zhang, Ching-Wen, Beth Hurst, and Annice McLean. "How fast is fast enough? Education students' perceptions of email response time in online courses." Journal of Educational Technology Development and Exchange (JETDE) 9, no. 1 (2016)

This article or document was made available through BearWorks, the institutional repository of Missouri State University. The work contained in it may be protected by copyright and require permission of the copyright holder for reuse or redistribution.

For more information, please contact BearWorks@library.missouristate.edu. 
Chang, C., Hurst, B., \& McLean, A. (2016). How Fast is Fast Enough? Education Students' Perceptions of Email Response Time in Online Courses. Journal of Educational Technology Development and Exchange,

9(1), 1-11.

\title{
How Fast is Fast Enough? Education Students' Perceptions of Email Response Time in Online Courses
}

\author{
Ching-Wen Chang \\ Missouri State University \\ Beth Hurst \\ Missouri State University \\ Annice McLean \\ Missouri State University
}

\begin{abstract}
An unintended consequence of the ubiquitous use of email for online course communication is that some faculty believe students now seem to expect 24/7 access to their instructors. Emails come from students at all hours of the day and night, and they seem to expect answers quickly. The purpose of this study was to determine the perceptions of college students in the field of education of how long they expect to wait for their online instructors to respond to their emails and how quickly they respond to emails from their online instructors. A voluntary, anonymous survey was sent to undergraduate and graduate education students enrolled in at least one online class during two semesters at a Midwest university in the United States. The results of the survey indicated that the vast majority of the students (91\%) consider 24 hours an acceptably responsive return rate time, and the same majority (91\%) reported they consider 24 hours an acceptably responsive time for them to return emails they receive from their online instructors.
\end{abstract}

Keywords: email response time, response time, online communication, distance education, student expectations

\section{Introduction}

Distance learning, the education model that allows students to get their education from anywhere at any time, has grown and expanded faster than traditional seated programs, and enrollment in online education has hit an all-time high in higher education
(Allen \& Seaman, 2013; Cole, Shelley, \& Swartz, 2014). Correspondingly, interaction and communication in a Web-based learning environment is critical in order to build community and overcome the isolation online students often feel (Carlson \& Repman, 2000; Chang, 2009). This need is corroborated in a study by Li, Finley, Pitts, and Guo (2010) 
who found that learners prefer asynchronous tools such as email to communicate with their instructors. It also coincides with the findings of a study by Chang, Hurst, and McLean (2015) who discovered that $97 \%$ of the students surveyed preferred to receive course correspondence from online instructors via email.

Communication is clearly essential for student satisfaction and success of any online course, and email appears to be the medium of choice, even among today's online learners. What this study focuses on is education students' expectations concerning the speed of responses to emails in their distance learning courses. Moore (1991), one of the early theorists in distance education, found that a prompt email response is one way to reduce the transactional distance between instructors and learners. Transactional distance is “... a psychological and communications gap, a space of potential misunderstanding between the inputs of instructor and those of the learner" (Moore, 1991, p. 2) created by the physical distance separating online instructors from their learners.

More recently, Elbeck and Song (2011) found that "Given students report greatest use of e-mail to communicate with instructors, students often expect an instant response" (p. 54). Thus, one might assume the current generation of online learners would expect response times on par with texting and social media.This raises the question of how fast is "fast enough." That is how quickly does this generation of distance learners expect an email response from their online instructors, and how quickly they respond to emails received from an online instructor. A survey was conducted to answer these questions. Before providing the survey results however, a review of relevant literature provides a foundation of the topic.

\section{Relevant Literature}

Many students find email an effective way for instructors to communicate with them (Chang et al., 2015; Frey, Faul, \&Yankelov, 2003; Ortiz-Rodríguez, Telg, Irani, Roberts, \& Rhoades, 2005; Woods, 2002), and according to Dahlstrom (2014), 99\% of institutions offering online courses use a learning management system that includes email. Nevertheless, Weinstock (2004) found that students often view email as "a form of telepathy-the instantaneous communication of an uncensored thought, often with the expectation of an immediate response" (p. 380). He suggested that instructors can help teach students patience by not expecting instant responses. Elbeck and Song (2011) found that if students were provided a template for the best way to construct an email for a particular instructor, then instructors were more likely to respond in a timely manner.

In their study to determine faculty and student expectations of email communication, Floral et al. (2010) found that faculty perceived themselves as more accessible to students than the students did. Students reported that because they were paying for their instructors' time, they expected timely responses to their emails. Additionally, Foral et al. were surprised to learn that the students in the campus courses expected a quicker response from an email than did the online students. Overall, students reported they expected a response to an email within 24 hours. Foral et al. suggested that online instructors provide virtual office hours and explain to students their policy for how soon they will respond to emails so students know what to expect. This 24-hour window was reiterated by Argon (2003) who stated, "My rule of thumb is to answer student e-mail associated with a current class within twentyfour hours unless stated otherwise. Students 
need to feel that their messages are valued by the instructor and have the same amount of priority as any other message" (p. 64). White and Weight (1999) also contend that when instructors respond within 24 hours this shows students the instructor is involved in the class.

Duran, Kelly, and Keaten (2005) found from their study of faculty use and perceptions of email, that faculty received an average of 15 emails from students per week. In addition to the emails received from students, they typically initiated about seven emails each week. Duran et al. found that "some faculty are unhappy about the quantity of email, the time it takes to respond to student email, and being 'on call' 24 hours a day with no separation between home and work" (p. 171). To mitigate this problem, many institutions have instituted policies or, at a minimum, made recommendations to their online faculty. For example, instructor response time policy recommendations at Cape Fear Community College (Coyle, 2014) include the following:

- Explicitly state response times in the syllabus or elsewhere in order to set expectations for the students such as responding to all emails within 24 hours during the week; and any communication after 5:00 p.m. on Friday will be returned on Monday unless there is a weekend activity.

- Tell students to try a different method of contact if they have not heard back from the instructor within 24 hours.

- The instructor will only respond to emails from the school's official email system.

Sheer and Fung (2007) found in their study of course email communication between faculty and students that emails can help build relationships between teachers and students. They also found that when instructor emails were helpful and prompt, it increased students' perceptions of positive relationships with their instructors, which led to positive teaching evaluations at the end of the course. Leidman and Piwinsky (2009) found in their study that $97 \%$ of faculty tried to respond to emails in 24 hours or less. Interestingly, these response patterns were similar whether or not a statement was included in the syllabus concerning how quickly they would respond to emails.

Argon (2003) also stated that specific ways of increasing presence in the online classroom included "promptly answering e-mails" (p. 64), and Waterhouse and Rogers (2004) contend that if instructors gave students a time frame for responses, there would be fewer repeat emails. Thus, there appears to be strong consensus among both researchers and practitioners that promptly responding to email communication in the distance learning environment is essential. What follows are the details of this study that attempts to determine what the term promptly actually means in the online learning environment.

\section{Purpose of the Study}

An unintended consequence of the ubiquitous use of email for online course communication is that some faculty believe students now seem to expect $24 / 7$ access to their instructors. Emails come from students at all hours of the day and night, and they seem to expect answers quickly. The purpose of this study was to determine the perceptions of college students in the field of education regarding how long they expect to wait for their online instructors to respond to their emails and how long it typically takes them to respond to emails they receive from their online instructors. The findings of this study provide online instructors with some indicators and reminders of the importance of appropriate 
communication response guidelines. Being more aware of the need for timely response from the perspective of students in online courses indicates the necessity to establish clearly stated verbiage of what students should expect from their instructors. This in turn will assist practitioners in distance learning to set more accurate parameters concerning response time to student communication in order to mitigate transitional distance and improve communication building.

\section{Method and Participants}

A link to a voluntary, anonymous questionnaire hosted on SurveyMonkey® was sent to 643 students in the field of education enrolled in at least one online class during the fall 2015 and spring 2016 semesters to determine their perceptions of how quickly they expect their online instructors to respond to their emails and how quickly they typically respond when they receive an email from an instructor.

This study used the survey design. Survey research is a pre-experimental, descriptive research method used to "...identify trends in attitudes, opinions, behaviors, or characteristics" (Creswell, 2005, p. 52) when researchers wish to collect data on phenomena that cannot be directly observed such as response times to emails in an online course. According to Gay, Mills, and Airasian (2009), a survey questionnaire is "an instrument to collect data that describes one or more characteristics of a specific population" (p. 175) in order to "...learn about their characteristics, opinions, attitudes, or previous experiences" (Leedy \& Ormrod, 2005, p. 183). Students who responded to the survey provided their opinions about email response time to and from online instructors.

A sample of convenience was utilized based on students in the field of education enrolled in at least one online class at a Midwest university in the United States. All of the online courses at this university are housed in the Blackboard Learn ${ }^{\mathrm{TM}}$ learning management system. Blackboard Learn (2016) offers "education technologies and engaging interfaces focused on the learner" (p. 1) including an email tool. A SurveyMonkey link to the voluntary, anonymous survey was sent via email to students enrolled in at least one online undergraduate course in the College of Education including elementary education, middle school, high school, instructional technology, literacy, and special education, and to students enrolled in at least one graduate online course in the same educational areas of study. Based on the survey results, the response rate was $35 \%$ or 227 valid responses were returned out of 643 sent.

In order to determine the demographics of the students who took the survey, the survey asked participants for their gender, age, number of online courses taken, and level in school. Table 1 shows the gender, age, number of online courses taken, and level in school.

Students who responded to the survey were predominately female ( $85 \%$ female). The age groupings started with the traditional undergraduate college age of 18-22. The second group represents the typical graduate student age range. After that they were grouped for convenience. Close to half of the students (44\%) were 18-22 years old, while $32 \%$ were $23-30,15 \%$ were $31-40$, and $10 \%$ were 41 to 59 years of age. More than half $(51 \%)$ of the students have taken more than four online courses, while 19\% have taken four online courses, $13 \%$ have taken three, and $17 \%$ have taken only one or two online courses. Over half $(56 \%)$ of the students who responded to the survey were undergraduates and $38 \%$ were graduate students. 
Table 1. Demographic summary

\begin{tabular}{|c|c|c|}
\hline & $n$ & $\%$ \\
\hline \multicolumn{3}{|l|}{ Gender } \\
\hline Female & 194 & 85 \\
\hline Male & 26 & 11 \\
\hline Chose not to report & 1 & $0.1(2221)$ \\
\hline \multicolumn{3}{|l|}{ Age } \\
\hline $18-22$ & 99 & 44 \\
\hline $23-30$ & 72 & 32 \\
\hline $31-40$ & 34 & 15 \\
\hline $41-59$ & 22 & 10 \\
\hline Over 60 & 0 & $0(227)$ \\
\hline \multicolumn{3}{|l|}{ Number of online courses taken } \\
\hline 1 & 19 & 8 \\
\hline 2 & 21 & 9 \\
\hline 3 & 29 & 13 \\
\hline 4 & 42 & 19 \\
\hline More than 4 & 115 & $51(226)$ \\
\hline \multicolumn{3}{|l|}{ Level in school } \\
\hline Undergraduate & 127 & 56 \\
\hline Graduate & 86 & 38 \\
\hline Non-degree seeking & 11 & $5(224)$ \\
\hline
\end{tabular}

$\mathrm{n}=227$ respondents

\section{Procedures and Data Collection}

After receiving permission to conduct the study from the university's Institutional Review Board, an email was sent to 643 students in the field of education enrolled in at least one online class at the universitywith a link to a survey hosted in SurveyMonkey ${ }^{\circledR}$ in which they were asked if they would complete a brief survey to provide their opinions about email response time. Students were informed in the email that their survey responses were completely anonymous, their participation was voluntary, and they could stop the survey at any time without completing it. The data collected was used in aggregate so individual participants could not be identified. The responses gathered were housed on a secure server to which only the researchers had access.

Participants first responded to questions related to demographic information including gender, age, number of online courses taken, and level in school. The participants were then asked to respond to a series of statements using a five-point Likert scale with strongly agree (5), agree (4), neutral (3), disagree (2), 
and strongly disagree (1) regarding what they think is an appropriate time to hear back from online instructors and an appropriate time for them to respond to emails they receive from their online instructors. Students were also requested to write in any comments they would like to make concerning email response time.

\section{Results}

As shown in Table 2, of the 227 valid responses to the survey, $46 \%$ expected to hear back from their online instructors within hours of emailing them, and $78 \%$ expected to hear back the same day. Over half of the students $(61 \%)$ disagreed or strongly disagreed that if they emailed the instructor in the evening, they expected to hear back that same evening. Half of the students (51\%) understood that it took a couple of days for an instructor to return an email. Over half of the students $(57 \%)$ did not expect their online instructors to respond to their emails on weekends and holidays, but $23 \%$ did expect a response on weekends and holidays. Overall, a vast majority of the students (91\%) considered 24 hours a responsive return rate.

Table 2. Online students' preferred email response time from instructors

\begin{tabular}{|c|c|c|c|c|c|}
\hline & SA & A & $\mathrm{N}$ & $\mathrm{D}$ & $\mathrm{SD}$ \\
\hline $\begin{array}{l}\text { When I email my instructor, I expect to hear back } \\
\text { within a few hours. }\end{array}$ & 33 & 69 & 57 & 61 & 3 \\
\hline $\begin{array}{l}\text { When I email my instructor, I expect to hear back } \\
\text { the same day. }\end{array}$ & 70 & 102 & 23 & 26 & 1 \\
\hline $\begin{array}{l}\text { I work on coursework in the evenings, so when } \\
\text { I email my instructor, I expect to hear back the } \\
\text { same evening. }\end{array}$ & 8 & 27 & 53 & 115 & 19 \\
\hline $\begin{array}{l}\text { I work on coursework on the weekends and } \\
\text { holidays, so when I email my instructor, I expect } \\
\text { to hear back on the weekends and holidays. }\end{array}$ & 9 & 42 & 44 & 94 & 33 \\
\hline $\begin{array}{l}\text { We all have different work schedules, so when I } \\
\text { email my instructor, I understand if I have to wait } \\
\text { to hear back for a couple of days. }\end{array}$ & 36 & 77 & 40 & 59 & 11 \\
\hline $\begin{array}{l}\text { I consider a responsive online course as one that } \\
\text { has a response from my instructor within } 24 \\
\text { hours. }\end{array}$ & 115 & 89 & 16 & 4 & 0 \\
\hline $\begin{array}{l}\text { I prefer to do the weekly coursework for an } \\
\text { online course in one sitting so it is fine with me if } \\
\text { my instructor answers my emails once per week. }\end{array}$ & 24 & 31 & 50 & 86 & 31 \\
\hline
\end{tabular}

$\mathrm{n}=227$ respondents 
As shown in Table 3, of the 227 students who responded to the survey, a majority $(68 \%)$ reported they usually responded to an email from their online instructors within hours of receiving the email; a strong majority $(91 \%)$ reported they responded the same day; $66 \%$ reported that if they received an email from an instructor in the evening, they responded to the instructor that same evening. Students were split between believing the instructor should understand if it took them a couple of days to return an email with $40 \%$ agreed or strongly agreed, 38\% disagreed or strongly disagreed, and $22 \%$ neutral. Over half of the students $(65 \%)$ reported they responded to emails from their online instructors on weekends and holidays, and $20 \%$ did not. Overall, a vast majority of the students (91\%) considered 24 hours a responsive time to return instructor emails.

Table 3. Online students' own email response time to instructors

\begin{tabular}{|c|c|c|c|c|c|}
\hline & $\mathrm{SA}$ & A & $\mathrm{N}$ & $\mathrm{D}$ & $\mathrm{SD}$ \\
\hline $\begin{array}{l}\text { When my instructor emails me, I usually respond } \\
\text { within a few hours. }\end{array}$ & 58 & 92 & 30 & 37 & 2 \\
\hline $\begin{array}{l}\text { When my instructor emails me, I usually respond } \\
\text { the same day. }\end{array}$ & 91 & 107 & 11 & 10 & 0 \\
\hline $\begin{array}{l}\text { I work on coursework in the evenings, so when } \\
\text { my instructor emails me, I usually respond the } \\
\text { same evening. }\end{array}$ & 49 & 96 & 38 & 33 & 4 \\
\hline $\begin{array}{l}\text { I work on coursework on the weekends and } \\
\text { holidays, so when my instructor emails me, I } \\
\text { usually respond the same weekends and holidays. }\end{array}$ & 43 & 98 & 34 & 34 & 9 \\
\hline $\begin{array}{l}\text { We all have different work schedules, so when } \\
\text { I respond to my instructors, it is understandable } \\
\text { if they have to wait to hear back from me for a } \\
\text { couple of days. }\end{array}$ & 15 & 72 & 48 & 67 & 16 \\
\hline $\begin{array}{l}\text { I consider myself to be an active participant in an } \\
\text { online course when I respond to my instructors' } \\
\text { questions within } 24 \text { hours. }\end{array}$ & 78 & 123 & 13 & 6 & 0 \\
\hline $\begin{array}{l}\text { I prefer to do the weekly coursework for an } \\
\text { online course in one sitting so I prefer to answer } \\
\text { emails once per week. }\end{array}$ & 21 & 28 & 47 & 89 & 33 \\
\hline $\begin{array}{l}\text { I want my instructors to respond to my emails } \\
\text { in a timely manner, so I hold myself to the same } \\
\text { standard in returning emails from my instructors. }\end{array}$ & 116 & 86 & 14 & 3 & 0 \\
\hline
\end{tabular}


In addition to students responding to the Likert scale questions, a final open-ended question provided students the opportunity to provide comments regarding email response time in online courses. Several students chose to explain the answers they provided on the scale. One student reported that it was helpful if instructors were not able to answer immediately that they send an email that stated something such as "I received your email and will get back with you as soon as I can." Another student reported "the email expectations of the teacher need to be laid out in the beginning of the course."

\section{Discussion and Conclusion}

So, how fast is fast enough? There appears to be a strong overall consensus among both online faculty and online learners that a window of 24 hours for responding to email communications is acceptably responsive. The results of this study match the advice of White and Weight (1999) who stated responding to students within 24 hours or sooner if possible is an important part of online teaching because this shows students the instructor is actively involved in class. While some online instructors feel they are on call $24 / 7$, this study corroborates the literature that the majority of distance learners do not have the expectation of an immediate response.Today is a world of electronic communication where nearly instantaneous response times are possible via texting and social media outlets. However, the overwhelmingly preferred method of communication in online courses today is email, and based on these and other findings, neither online educators nor online learners expect immediate email responses.

There also seems to be a consensus that the best way to mitigate email response time issues that might occur is for instructors to explicitly state their guidelines for online communication, whether in the syllabus, in an introductory email or announcement, by institutional policy, or a combination of these approaches (Coyle, 2014). Waterhouse and Rogers (2004) recommended that instructors tell students what time frame they could expect an email response. They mentioned, "A clearly stated response time helps constrain frustration when students don't hear back from you in what they consider to be a timely fashion. It also reduces the number of repeat e-mails" (p. 30). A specific course requirement, weekend activity, or other extenuating circumstance may hinder a published policy, but once again, explicitly communicating expectations ahead of time is usually sufficient to avoid miscommunication and frustrations.

Dahlstrom (2014) reported that 99\% of institutions offering distance education courses utilized a learning management system or LMS. In addition to the traditional email system provided by the institution, learning management systems also have a built-in email tool that can further assist faculty and students with communicating by email. Moreover, the announcement function of virtually all LMSs includes the option to automatically email the text of an announcement to the users in addition to posting the 
announcement. Thus, more often than not, there are multiple ways to communicate by email in today's distance learning environment. Email communication clearly is the preferred method of online communication and is fast enough.

\section{Future Research}

When results of a study corroborate findings in the current literature, it can be a rewarding experience. Nevertheless, additional research should be conducted. For example, researchers could replicate the current study to determine the reliability of these findings. Also, because these results were found at a public, four-year institution, it would be useful to attempt to determine if the 24-hour response paradigm crossed institutional types. That is, would these same findings hold for a two-year institution, a fouryear private institution, or a technical institute? The participants in this study were undergraduate and graduate education students. So, would a change of discipline affect the outcome? Further, can the 24-hour response paradigm hold for humanities, or science, or engineering majors? Finally, can similar findings be collected from institutions in other countries? Any or all of these would be interesting and useful future research projects.

Distance education is here to stay and email is the preferred method of communication in distance education. Further research could lead to interesting and useful findings that were not anticipated, resulting in new avenues of study to explore. Further research is encouraged to increase the understanding of communication in distance education and expand the current body of knowledge. 


\section{References}

Allen, I., \& Seaman, J. (2013).Changing course: Ten years of tracking online education in the United States.Retrieved from http://www.onlinelearningsurvey. com/reports/ changingcourse.pdf

Argon, S. (2003).Creating social presence in online environments. New Directions for Adult and Continuing Education, 100, 5768.

Blackboard Learn. (2016). What we do. Retrieved from http://www.blackboard. com/about-us/index.aspx

Chang, C-W.(2009). Efficacy of interaction among college students in a web-based environment.Journal of Educational Technology Development and Exchange, 2(1), 17-32.

Chang, C-W., Hurst, B., \& McLean, A. (2015). You've got mail: Student preferences of instructor communication in online courses in an age of advancing technologies. Journal of Educational Technology Development and Exchange, 8(1), 39-47.

Cole, M., Shelley, D., \& Swartz, L. (2014). Online instruction, e-learning, and student satisfaction: A three year study. The International Review of Research in Open and Distance Learning, 15(6), 111-131.

Coyle, R. (2014). Instructor response time: Setting expectations. Retrieved from http://cfcc.edu/onlinefaculty/instructorresponse-time-setting-expectations/

Creswell, J. W. (2005). Educational research: Planning, conducting, and evaluating quantitative and qualitative research. Upper Saddle River, NJ: Pearson.

Dahlstrom, E., D., Brooks, D. C.,\& Bichsel, J. (2014). The current ecosystem of learning management systems in higher education: Student, faculty, and IT perspectives.
Louisville, CO: EDUCAUSE Center for Analysis and Research.

Duran, R.L., Kelly, L., \&Keaten, J.A. (2005). College faculty use and perceptions of electronic mail to communicate with students.Communication Quarterly, 53(2), 159-176.

Elbeck, M., \& Song, M. (2011).Improving instructor response to student emails using template and reminder interventions. Journal of Asynchronous Learning Networks, 15(3), 54-67.

Floral, P. A., Turner, P.D., Monaghan, M.S., Walters, R.W., Merkel, J.J., Lipschultz, J.H., \&Lenz, L.L. (2010).Faculty and student expectations and perceptions of e-mail communication in a campus and distance doctor of pharmacy program. AmericanJournal of Pharmaceutical Education, 74(10), 1-11.

Frey, A., Faul, A., \&Yankelov, P. (2003). Student perceptions of web-assisted teaching strategies.Journal of Social Work Education,39(3), 443-457.

Gay, L. R., Mills, G. E., \&Airasian, P. W. (2009). Educational research: Competencies for analysis and applications (9th ed.). Upper Saddle River, NJ: Prentice Hall.

Glasow, P. (2005, April). Fundamentals of survey research methodology. Retrieved from http://www.mitre.org/sites/default/ files/pdf/05 0638.pdf

Leedy, P. D., \&Ormrod, J. E. (2005).Practical research: Planning and design (8th ed.). Upper Saddle River, NJ: Prentice Hall.

Leidman, M. B., \&Piwinsky, M. J. (2009).The perpetual professor in the 21 st century university. Indiana, PA: Indiana University of Pennsylvania.Retrieved from ERIC database (ED 506747)

Li, L., Finley, J., Pitts, J., \&Guo, R. (2010). Which is a better choice for studentfaculty interaction: Synchronous or asynchronous communication? Journal of 
Technology Research, 2,1-12.

Moore, M. G. (1991). Distance education theory. The American Journal of Distance Education, 5(3), 1-6.

Ortiz-Rodríguez, M., Telg, R.W. Irani, T., Roberts, T.G., \& Rhoades, E. (2005). College students' perceptions of quality in distance education: The importance of communication. Quarterly Review of Distance Education, 6(2), 97-105.

Sheer, V.C., \& Fung, T.K. (2007). Can email communication enhance professor-student relationship and student evaluation of professor? Some empirical evidence. Journal of Educational Computing Research, 37(3), 289-306.

Waterhouse, S.,\& Rogers, R. (2004). The importance of policies in e-learning instruction. EDUCAUSE Quarterly, 27(3), 28-39.

Weinstock, J.A. (2004). Respond now! E-mail, acceleration, and a pedagogy of patience. Pedagogy, 4(3), 365-383.

White, K.W., \& Weight, B.H. (1999).Online teaching guide: A handbook of attitudes, strategies, and techniques for the virtual classroom. Boston, MA: Allyn \& Bacon.

Woods, R. (2002). How much communication is enough in online courses? Exploring the relationship between frequency of instructor-initiated personal email and learners' perception of and participation in online learning.International Journal of Instructional Media, 29(4), 377-394.

\section{Contact the Author}

\section{Ching-Wen Chang}

Associate Professor, College of Education, Missouri State University

Email: CChang@missouristate.edu

\section{Beth Hurst}

Associate Professor, College of Education, Missouri State University

Email: BethHurst@missouristate.edu

\section{Annice McLean}

Associate Professor, College of Education, Missouri State University

Email: AMcLean@missouristate.edu 